\title{
Nitrous oxide in coastal waters
}

\author{
Hermann W. Bange, Spyridon Rapsomanikis, and Meinrat O. Andreae \\ Biogeochemistry Department, Max Planck Institute for Chemistry, Mainz, Germany
}

\begin{abstract}
We determined atmospheric and dissolved nitrous oxide $\left(\mathrm{N}_{2} \mathrm{O}\right)$ in the surface waters of the central North Sea, the German Bight, and the Gironde estuary. The mean saturations were $104 \pm 1 \%$ (central North Sea, September 1991), $101 \pm 2 \%$ (German Bight, September 1991), $99 \pm 1 \%$ (German Bight September 1992), and 132\% (Gironde estuary, November 1991). To evaluate the contribution of coastal areas and estuaries to the oceanic emissions we assembled a compilation of literature data. We conclude that the mean saturations in coastal regions (with the exception of estuaries and regions with upwelling phenomena) are only slightly higher than in the open ocean. However, when estuarine and coastal upwelling regions are included, a computation of the global oceanic $\mathrm{N}_{2} \mathrm{O}$ flux indicates that a considerable portion (approximately $60 \%$ ) of this flux is from coastal regions, mainly due to high emissions from estuaries. We estimate, using two different parameterizations of the air-sea exchange process, an annual global sea-to-air flux of 11$17 \mathrm{Tg} \mathrm{N} \mathrm{N}_{2} \mathrm{O}$. Our results suggest a serious underestimation of the flux from coastal regions in widely used previous estimates.
\end{abstract}

\section{Introduction}

Nitrous oxide $\left(\mathrm{N}_{2} \mathrm{O}\right)$ is, apart from molecular nitrogen, the most abundant nitrogen compound in the atmosphere. Global long-time measurement series of tropospheric $\mathrm{N}_{2} \mathrm{O}$ show an annual growth rate of about $0.25 \% \mathrm{yr}^{-1}$ [Weiss, 1981; Prinn et al., 1990; Khalil and Rasmussen, 1992]. Because of its chemical inertness, $\mathrm{N}_{2} \mathrm{O}$ has a long atmospheric residence time of about 110-180 years [Cicerone, 1989; Prinn et al., 1990; Ko et al., 1991; Minschwaner et al., 1993]. In the stratosphere it is the major source of nitric oxide radicals which play an important role in the depletion of stratospheric ozone [Crutzen and Schmailzl, 1983]. The characteristic absorption of $\mathrm{N}_{2} \mathrm{O}$ in the infrared range of the atmospheric window of the Earth makes it act as a greenhouse gas. Its contribution to the anthropogenic greenhouse effect was estimated to be 5-6\% [Lashof and Ahuja, 1990; Rodhe, 1990]. In view of both its great potential to influence directly or indirectly the world's climate and its increasing atmospheric concentrations, it is necessary to gain knowledge about the global budget of atmospheric $\mathrm{N}_{2} \mathrm{O}$. Recent compilations of sources and sinks of $\mathrm{N}_{2} \mathrm{O}$ indicate that natural sources (e.g., emissions from soils and the world's oceans) dominate the global budget [Khalil and Rasmussen, 1992; Bouwman et al., 1995]. The contribution of the world's ocean to the global emissions of atmospheric $\mathrm{N}_{2} \mathrm{O}$ was estimated to be about 13\% [Khalil and Rasmussen, 1992]. Most parts of the open ocean appear to be near equilibrium with the overlying atmosphere (the global mean saturation is about $103 \%$ ) [Weiss, 1978; Butler et al., 1989; Nevison et al., 1995]. However, the ocean is not a uniform ecosystem and an estimate of the oceanic emissions has to take into account the variability of the marine environment. For example, enhanced $\mathrm{N}_{2} \mathrm{O}$ concentrations were mainly found in the surface waters of biologically productive regions with a pronounced low-oxygen subsurface layer, for

Copyright 1996 by the American Geophysical Union.

Paper number 95GB03834.

0886-6236/96/95GB-03834\$10.00 example, the Arabian Sea [Law and Owens, 1990b; Naqvi and Noronha, 1991], the western Bay of Bengal [Naqvi et al., 1994], the Peruvian upwelling [Codispoti et al., 1992], and the tropical equatorial upwelling regions of the Pacific Ocean [Elkins et al., 1978; Butler et al., 1989; Weiss et al., 1992].

Here we present our measurements of dissolved and atmospheric $\mathrm{N}_{2} \mathrm{O}$ in three different coastal environments: (1) the central North Sea, (2) the German Bight, and (3) the Gironde estuary. On the basis of our own and on literature data, we evaluate the contribution of coastal regions to the oceanic emissions of atmospheric $\mathrm{N}_{2} \mathrm{O}$.

\section{Study Area Description and Cruise Tracks \\ Central North Sea and German Bight}

The North Sea forms part of the European shelf and can be classified as a coastal sea. Owing to the tidal motions, pronounced horizontal and vertical exchange and transport effects occur, which have substantial influence on the ecological conditions. Thermal stratification of the water column occurs in the central and northern North Sea during the summer months. The salinity and temperature distributions of the central North Sea are influenced by North Atlantic water masses which enter the North Sea from its northern boundary and which are subsequently transported south by a system of cyclonal (anticlockwise) circulation patterns along the British east coast [Otto et al., 1990].

The German Bight as part of the southeastern North Sea is influenced by North Atlantic water masses entering the North Sea via the British Channel and riverine inputs of the rivers Elbe and Weser. Owing to its characteristic function as a inixing vessel of oceanic waters and riverine waters, the German Bight generally shows lower salinities and a more pronounced seasonal variability of the water temperatures than the central North Sea. Furthermore, river plume fronts were observed due to the fresh water runoff from Elbe and Weser [Otto et al., 1990]. Therefore, typical flushing times for the German Bight (36 months) are about 2 times longer than those observed for the central North Sea [Meier-Reimer, 1979]. 
The first cruise took place in September 1991 on the German research vessel $\mathrm{R} / \mathrm{V}$ Alkor following a cruise track from the German Bight to the central North Sea and back. Twenty-six drifting stations with a duration of about 6 hours were located within the main investigation area around $54^{\circ} 30^{\prime}$ to $55^{\circ} 30^{\prime} \mathrm{N}$ and $1^{\circ}$ to $4^{\circ} \mathrm{E}$ (Figure 1 ).

The second campaign took place on the research platform R/P Nordsee located in the German Bight $\left(54^{\circ} 42^{\prime} \mathrm{N}, 7^{\circ} 10^{\prime} \mathrm{E}\right)$ in September 1992 (Figure 1).

\section{Gironde Estuary}

The Gironde estuary located on the southern Atlantic coast of France (around $45^{\circ} 30^{\prime} \mathrm{N}, 1^{\circ} 30^{\prime} \mathrm{E}$ ) is defined as the area between the confluence of the rivers Garonne and Dordogne north of Bordeaux and the North Atlantic. The degree of mixing and stratification of the water column in the estuary mainly depends on the amount of the seasonal riverine inputs. Therefore, the main upstream limit of the seawater intrusion varies between 75 $\mathrm{km}$ (low river flow) and $40 \mathrm{~km}$ (high river flow) from the mouth of the estuary [Jouanneau and Latouche, 1981].

The cruise took place on the French research vessel R/V Côte d'Aquitaine in November 1991. Our measurements were performed on nine sampling stations located along the horizontal salinity gradient within the Navigation channel which is the principle path of penetration for the seawater. Additionally, one station was located outside the estuary in coastal waters which were not affected by estuarine waters (Figure 2 ).

\section{Method}

$\mathrm{N}_{2} \mathrm{O}$ was determined with a gas chromatograph (GC) equipped with an electron capture detector (ECD). Details of the analysis are described by $\mathrm{H}$. W. Bange et al., (Nitrous oxide in the Baltic
Sea: Measurements and a model of the seasonal variability, submitted to Tellus, 1995; hereinafter refered to as H. W. Bange et al., 1995b). The analysis was carried out at $190^{\circ} \mathrm{C}$ with a packed column (Molecular sieve 5A) using a mixture of $\mathrm{Ar} / \mathrm{CH}_{4}$ $(95 \% / 5 \%)$ as carrier gas. The use of this mixture avoids possible interference from $\mathrm{CO}_{2}$ [Butler and Elkins, 1991] and enhances the reponse of $\mathrm{N}_{2} \mathrm{O}$ to electron capture. Ambient air was pumped continuously from the air inlets at the ship's masts into the lab. The locations of the air inlets were chosen to avoid contamination from the ship's engine. Seawater was pumped continuously from water depths of 3 to $4 \mathrm{~m}$ (Gironde) and from 6 to $7 \mathrm{~m}$ (central North Sea, German Bight) into an equilibrator installed in the lab. Equilibration of the seawater with sample air took place in a seawater/air equilibrator developed by R.F. Weiss (Scripps Institution of Oceanography, La Jolla, Ca.). The theoretical response time (i.e., the relaxation time) of the Weiss equilibrgtor for $\mathrm{N}_{2} \mathrm{O}$ is about $1-2 \mathrm{~min}$ and was verified in laboratory experiments by Butler et al. [1988] and Weiss et al. [1992]. For a detailed description of the theory and performance of the equilibrator see Butler et al. [1988] and Weiss et al. [1992]. We recorded no significant temperature differences between the seawater in situ and the water in the equilibrator during the cruises in the central North Sea and the Gironde estuary. During the campaign on the research platform we found a temperature enhancement of $0.5 \pm 0.1^{\circ} \mathrm{C}$. Concentrations and resulting saturation values were corrected for this difference. A temperature difference of $0.5^{\circ}$ leads to an error of about $1.6 \%$ in the saturation value. $\mathrm{N}_{2} \mathrm{O}$ production within the equilibrator was not observed. However, to exclude any possibility of $\mathrm{N}_{2} \mathrm{O}$ formation, the equilibrator was cleaned frequently.

Measurements of dissolved and atmospheric $\mathrm{N}_{2} \mathrm{O}$, and of two standard mixtures were performed when the ship was on station.

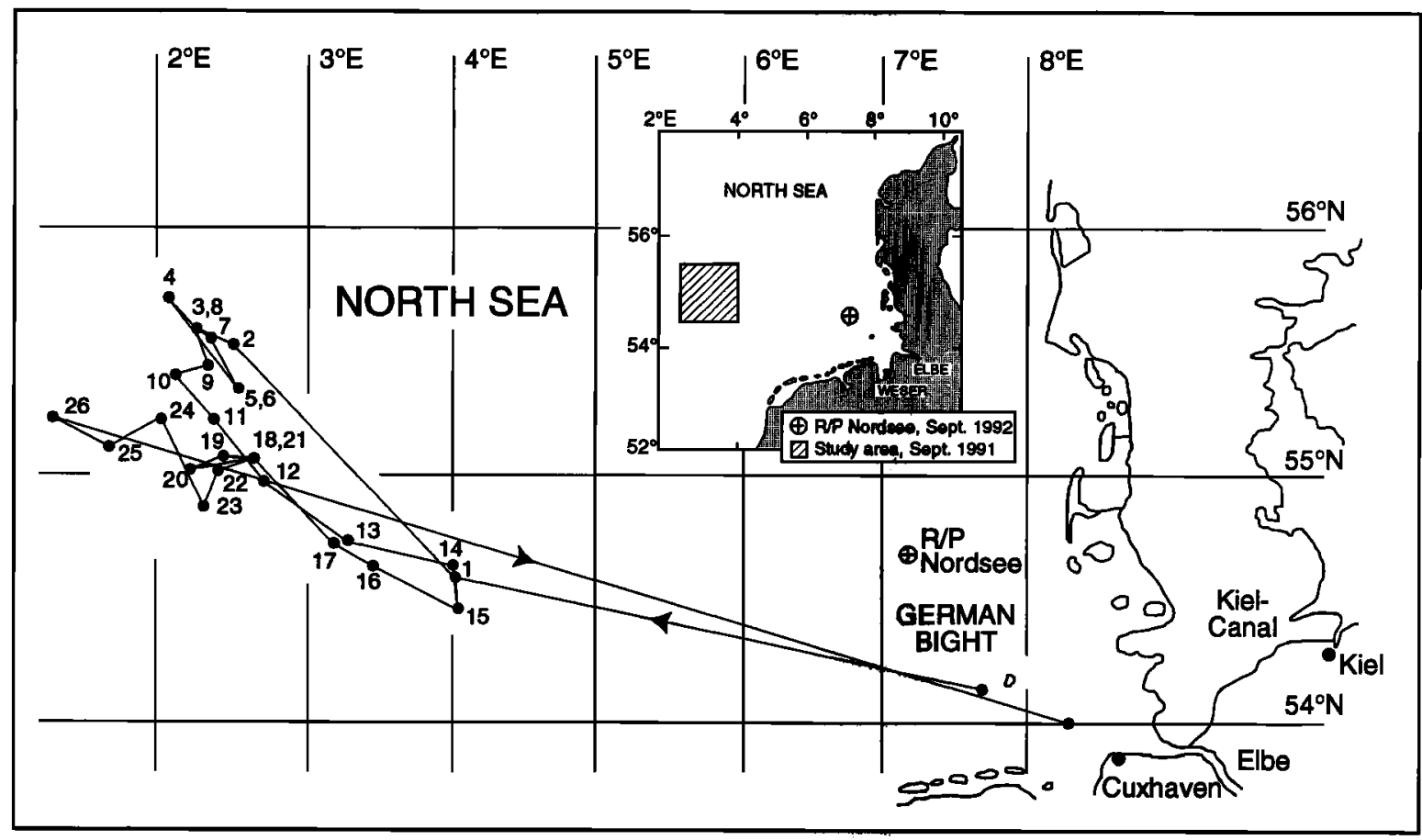

Figure 1. Cruise track and location of the sampling stations during September 1991 and September 1992 in the central North Sea and the German Bight. 


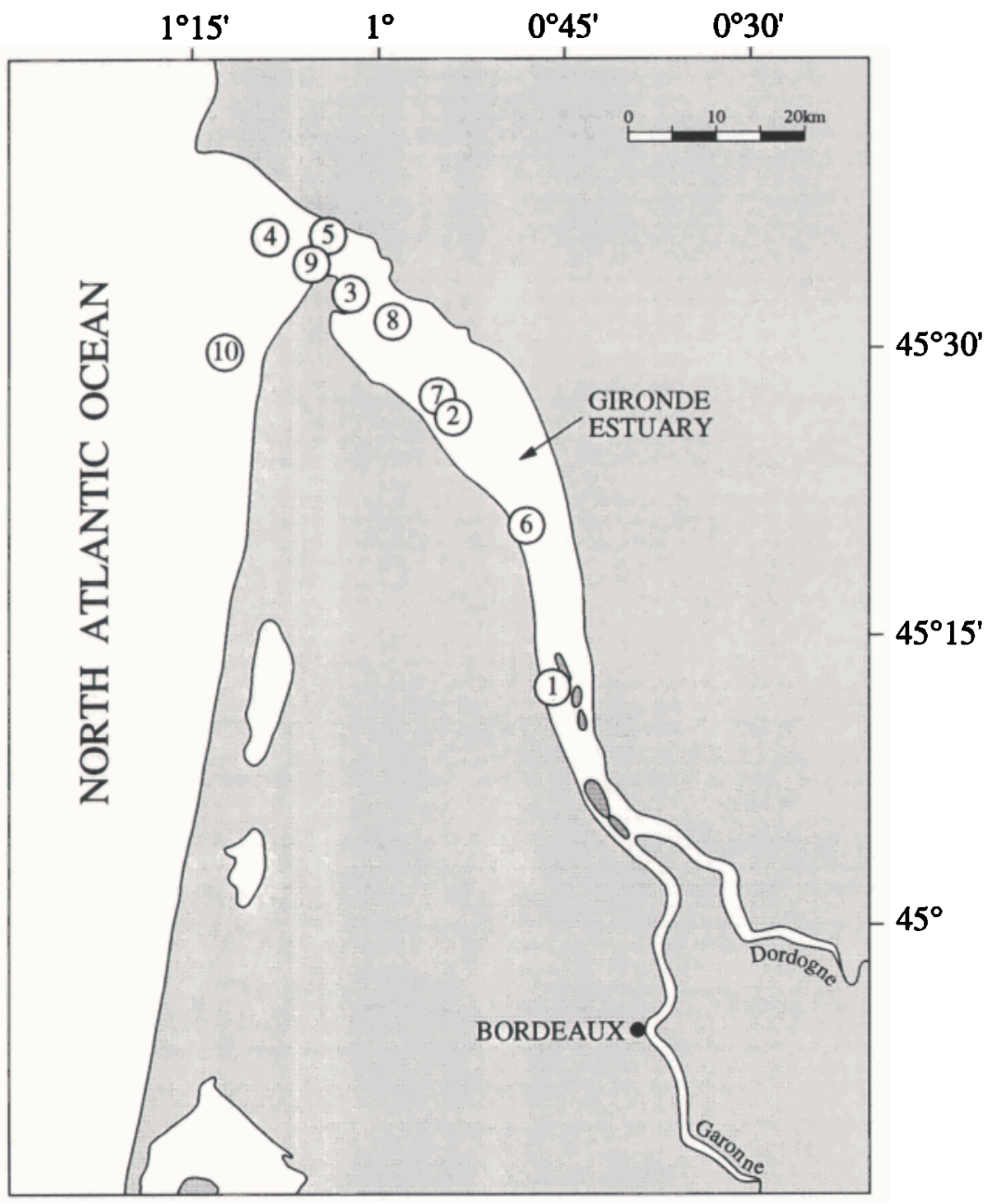

Figure 2. Locations of the sampling stations in the Gironde estuary.

The time for an analysis was 10 min (central North Sea and Gironde) and $25 \mathrm{~min}$ (German Bight). The number of measurements during a single station in the central North Sea and Gironde varied depending on the time spent at the position. During the Gironde expedition, measurements of the standard gas mixtures were performed during the time when the ship moved to the next station.

We used two sets of mixtures of $\mathrm{N}_{2} \mathrm{O}$ in synthetic air to create two-point calibration curves. On the cruises in September and November 1991 (central North Sea and Gironde) we used mixtures containing 298 and $378 \pm 5 \%$ parts per billion by volume (ppbv) $\mathrm{N}_{2} \mathrm{O}$ and in September 1992 (German Bight) we used standards with 315 and $335 \pm 2 \%$ ppbv $\mathrm{N}_{2} \mathrm{O}$. Both sets were gravimetrically prepared standard gas mixtures and the latter one has been calibrated by the manufacturer (DELSTE Steininger GmbH, Mühlhausen, Germany) against standards of the U.S. National Institute of Standards and Technology, Gaithersburg, Md ). Additionally, we measured the first standard pair in our laboratory against NIST-checked calibration gases. Cross calibration of the two sets also confirmed the certified values given by the manufacturer. It is well known that the ECD response to $\mathrm{N}_{2} \mathrm{O}$ shows a nonlinear behavior [Butler and Elkins, 1991] However, the characteristic response curve of the ECD used (Hewlett-Packard ECD) indicated that a correction within the range of the measurements presented in this paper was not necessary (Figure 3).

Saturation values were calculated as the ratio of dissolved $\mathrm{N}_{2} \mathrm{O}$ to the expected equilibrium value derived from the ambient air concentration by applying the solubility equation of Weiss and Price [1980]. Seawater temperature, salinity and atmospheric pressure were obtained from the ship's records and conductivitytemperature-depth (CTD) measurements performed during the cruises. The mean relative errors for the atmospheric mixing ratıo measurements were $0.7 \%$ (central North Sea, German Bight) and $0.8 \%$ (Gironde). We calculated the mean relative errors of the saturation to be $1.1 \%$ (central North Sea), 2.1\% (German Bight), and $1.5 \%$ (Gironde). The mean relative errors of the concentrations of dissolved $\mathrm{N}_{2} \mathrm{O}$ were $0.8 \%$ (central North Sea), $1.5 \%$ (German Bight), and 1.1\% (Gironde).

\section{Results and Discussion}

\section{Atmospheric Nitrous Oxide}

The mean atmospheric $\mathrm{N}_{2} \mathrm{O}$ mixing ratios were $332 \pm 3 \mathrm{ppbv}$ (central North Sea), $315 \pm 3$ ppbv (German Bight), and $325 \pm 3$ ppbv (Gironde) The observed atmospheric mixing ratios are in 


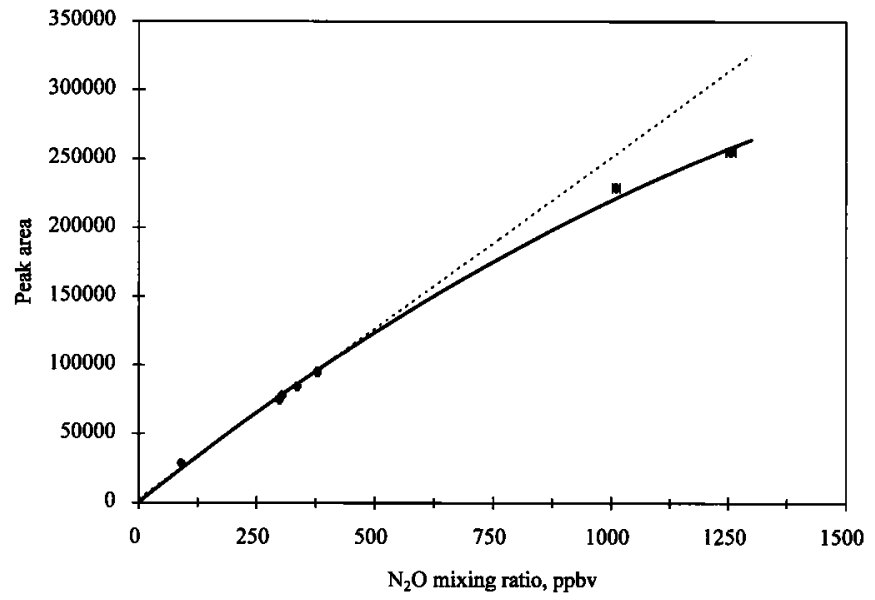

Figure 3. Characteristic response curve of the electron capture detector used in this study. We measured seven calibration gas mixtures: 90 and 1010 ppbv $\mathrm{N}_{2} \mathrm{O}$ in nitrogen $( \pm 5 \%$, Alltech, Inc.); 298, 304, 335, 378, and 1256 ppbv $\mathrm{N}_{2} \mathrm{O}$ in synthetic air ( \pm $2 \%$, Deuste Steininger GmbH, Mühlhausen, Germany). The solid line represents a linear fit through the points at 298 and $378 \mathrm{ppbv}$ $\mathrm{N}_{2} \mathrm{O}$ (correlation coefficient $r^{2}=0.9967$, number of samples $=$ 18). The dashed line indicates a quadratic fit $(y=275.42 x$ $0.0553 x^{2}, r^{2}=0.9981$, number of samples $=60$ ). Note that the points for the mixtures with a nitrogen matrix (90 and 1010 ppbv) do not fit very well. This might be caused by different reaction pathways within the electron capture detector due to the absence of oxygen.

disagreement with observations from global sampling networks which show a mean global value of about 307 ppbv $\mathrm{N}_{2} \mathrm{O}$ in 1987 with an average annual growth rate of about $1 \mathrm{ppb}$ [Khalil and Rasmussen, 1992]. However, our saturation data are not significantly affected by a potential offset in absolute calibration. Except for the cruise in September 1991 (central North Sea) the atmospheric mixing ratios showed no significant fluctuations from the mean values. However, in September 1991 pronounced peaks in the mixing ratio of $\mathrm{N}_{2} \mathrm{O}$ were observed (Figure 4). These peaks (e.g., on September 21-22) were closely correlated with the wind direction indicating that distinct air masses enriched with $\mathrm{N}_{2} \mathrm{O}$ were measured. The corresponding air mass back trajectories (computed for a height of approximately $750 \mathrm{~m}$ ) moved mostly over the British Isles [Krüger, 1992]. However, because of the Ekman spiral, one can expect a stronger south component of the wind for trajectories of lower layers. This suggests that continentally influenced air masses might have been present over the North Sea [Krüger, 1992]. Additionally, the enhancement of the $\mathrm{N}_{2} \mathrm{O}$ concentrations on September 21-22 was paralleled by increased concentrations of gaseous $\mathrm{HNO}_{3}, \mathrm{NH}_{3}$, aerosol $\mathrm{NO}_{3}{ }^{-}$, and $\mathrm{NH}_{4}{ }^{+} / \mathrm{NO}_{3}{ }^{-}$in rainwater board [Spokes et al., 1993; Sørensen et al., 1994]. Contamination due to influences from the ship's engine exhaust are not very likely because during the drift stations the ship was headed into the wind. Thus we conclude that the observed peaks of the $\mathrm{N}_{2} \mathrm{O}$ mixing ratios might be the result of an unusual meteorological situation leading to an accumulation of $\mathrm{N}_{2} \mathrm{O}$ in the atmospheric boundary layer rather than a contamination artifact.

\section{Dissolved Nitrous Oxide}

The mean $\mathrm{N}_{2} \mathrm{O}$ water concentrations and saturations are listed in Table 1. Differences in the $\mathrm{N}_{2} \mathrm{O}$ water concentrations in the central North Sea due to different water masses were small and seemed to be negligible. Water masses in the German Bight (identified by a different water temperature/salinity distribution) showed significantly lower $\mathrm{N}_{2} \mathrm{O}$ water concentrations and saturations (Table 1). Figure 5 shows the saturation of $\mathrm{N}_{2} \mathrm{O}$ in the

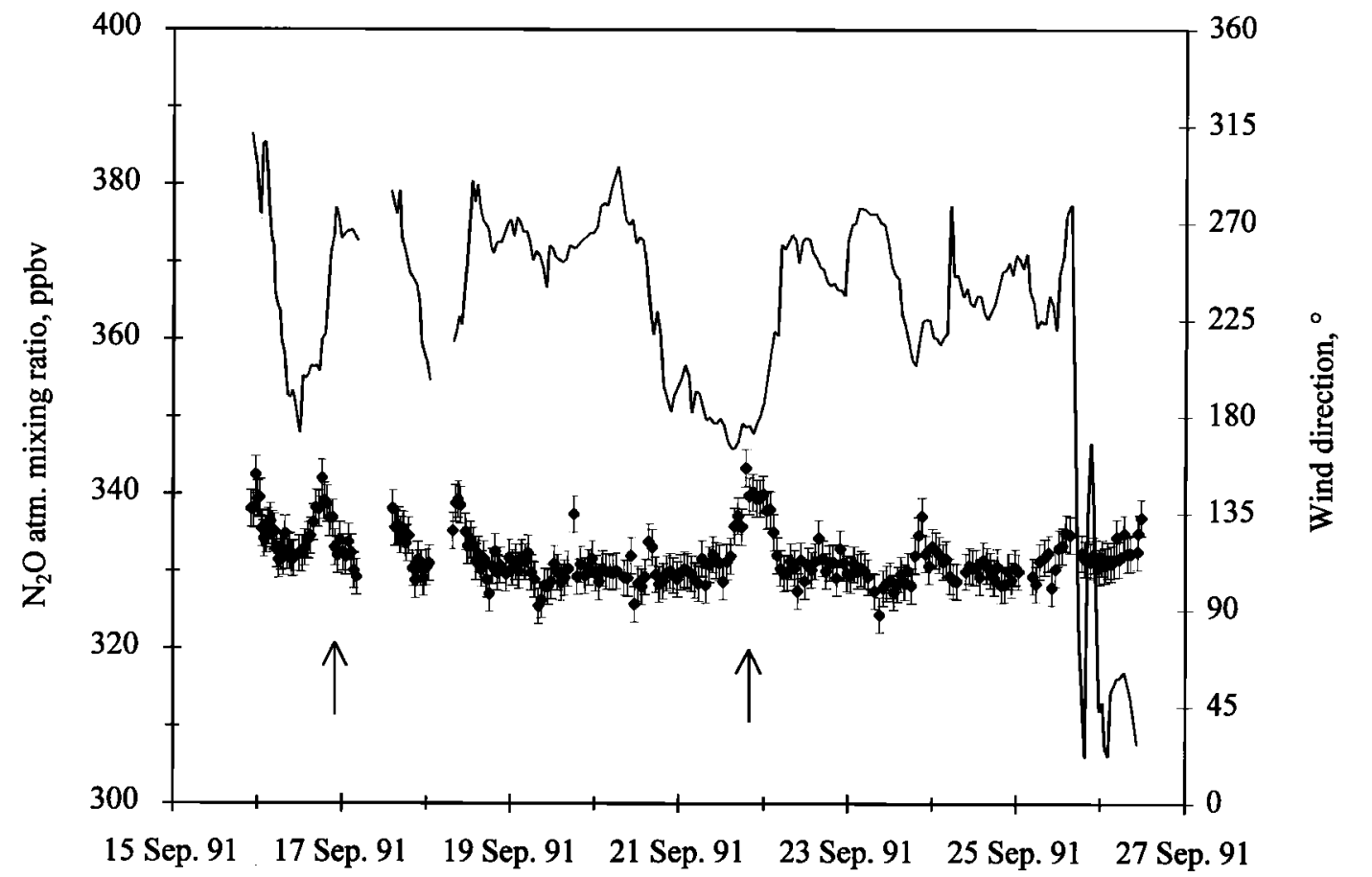

Figure 4. Atmospheric $\mathrm{N}_{2} \mathrm{O}$ mixing ratios in the central North Sea in September 1991. The solid line represents the wind direction and the two arrows indicate the occurrence of $\mathrm{N}_{2} \mathrm{O}$ peaks. 
Table 1. $\mathrm{N}_{2} \mathrm{O}$ Water Concentrations and Saturations in the Central North Sea, German Bight, and Gironde Estuary in September 1991 and September 1992

\begin{tabular}{|c|c|c|}
\hline Sample Location, Date, Station Number & $\begin{array}{l}\text { Dissolved } \mathrm{N}_{2} \mathrm{O}, \\
\quad \text { nmol L L }^{-1}\end{array}$ & $\begin{array}{c}\text { Mean } \\
\text { Saturation } \\
\pm 1 \text { s.d., } \\
\text { Percent }\end{array}$ \\
\hline Central North Sea, Sept. 1991, 1-26, (179) & $9.20 \pm 0.24$ & $103.7 \pm 1$ \\
\hline $\begin{array}{l}\text { German Bight, Sept. 1991, (17) } \\
\text { German Bight, Sept. 1992, (135) }\end{array}$ & $\begin{array}{l}8.66 \pm 0.22 \\
8.38 \pm 0.08\end{array}$ & $\begin{array}{l}100.7 \pm 1.6 \\
98.5 \pm 0.8\end{array}$ \\
\hline $\begin{array}{l}\text { Gironde estuary, Nov. 1991, } \\
1(2) \\
2(2) \\
3(4) \\
4(4) \\
5(2) \\
6(2) \\
7(2) \\
8(2) \\
9(2) \\
\text { Mean } 1-9\end{array}$ & $\begin{array}{c}18.6 \\
14.6 \\
10.3 \pm 0.4 \\
10.1 \pm 0.1 \\
10.7 \\
14.1 \\
12.1 \\
11.0 \\
10.3 \\
14.3^{\mathrm{a}}\end{array}$ & $\begin{array}{c}165 \\
136 \\
106 \pm 3 \\
105 \pm 0.6 \\
109 \\
129 \\
116 \\
110 \\
106 \\
132^{\mathrm{a}}\end{array}$ \\
\hline $10(2)$ & 10.0 & 102 \\
\hline
\end{tabular}

Number of measurements is in parentheses.

${ }^{\text {a }}$ Area-weighted

surface waters of the North Sea during the cruise in September 1991. The mean saturation for stations $1-26$ was $104 \pm 1 \%$ and for the German Bight $101 \pm 2 \%$. The time series of the $\mathrm{N}_{2} \mathrm{O}$ saturation measured on the R/P Nordsee in the German Bight in
September 1992 is shown in Figure 6. We observed no significant fluctuations from the mean value of $99 \pm 1 \%$. This value is in good agreement with the mean saturation observed in September 1991.

$\mathrm{N}_{2} \mathrm{O}$ measurements from Law and Owens [1990a] in the central North Sea in June 1986 and July 1987 yielded a mean saturation of $102 \%$ and are in excellent agreement with ours. However, these authors found a mean saturation for the German Bight of about $130 \%$, which is considerably higher than the values we observed in September 1991 and 1992. Further measurements in the German Bight were performed by Hanke and Knauth [1990]. They report $\mathrm{N}_{2} \mathrm{O}$ saturation values in the range of 82-220\% (May 1988) and 86-167\% (August 1988). The mean saturations were $120 \pm 41 \%$ (nine sampling stations, May 1988) and $114 \pm 36 \%$ (four sampling stations, August 1988). In view of the great scatter of these data and the analytical method used, the saturation values of Hanke and Knauth [1990] appear questionable. However, the disagreement between our observations in the German Bight and the two previous studies might be caused by seasonal differences in the discharge of the river Elbe (which shows high $\mathrm{N}_{2} \mathrm{O}$ concentrations [Hanke and $K$ nauth, 1990]) or in the microbial production of $\mathrm{N}_{2} \mathrm{O}$ in the water column [Law and Owens, 1990a]. Possible sedimentary production via denitrification seems to be negligible [Law and Owens, 1990a].

In the Gironde estuary we observed a decrease in $\mathrm{N}_{2} \mathrm{O}$ water concentrations with increasing salinity (Figure 7). The areaweighted mean saturation was $132 \%$. The saturation values ranged from $105 \pm 1.5 \%$ (station 4 , salinity $31.3 \%$ ) to $165 \pm 2.5 \%$ (station 1 , salinity $7.3 \%$ ). At station 10 , located outside the estuary, we observed a saturation of $102 \pm 1.5 \%$ (Table 1). The salinity at this station was $33.9 \%$ indicating that

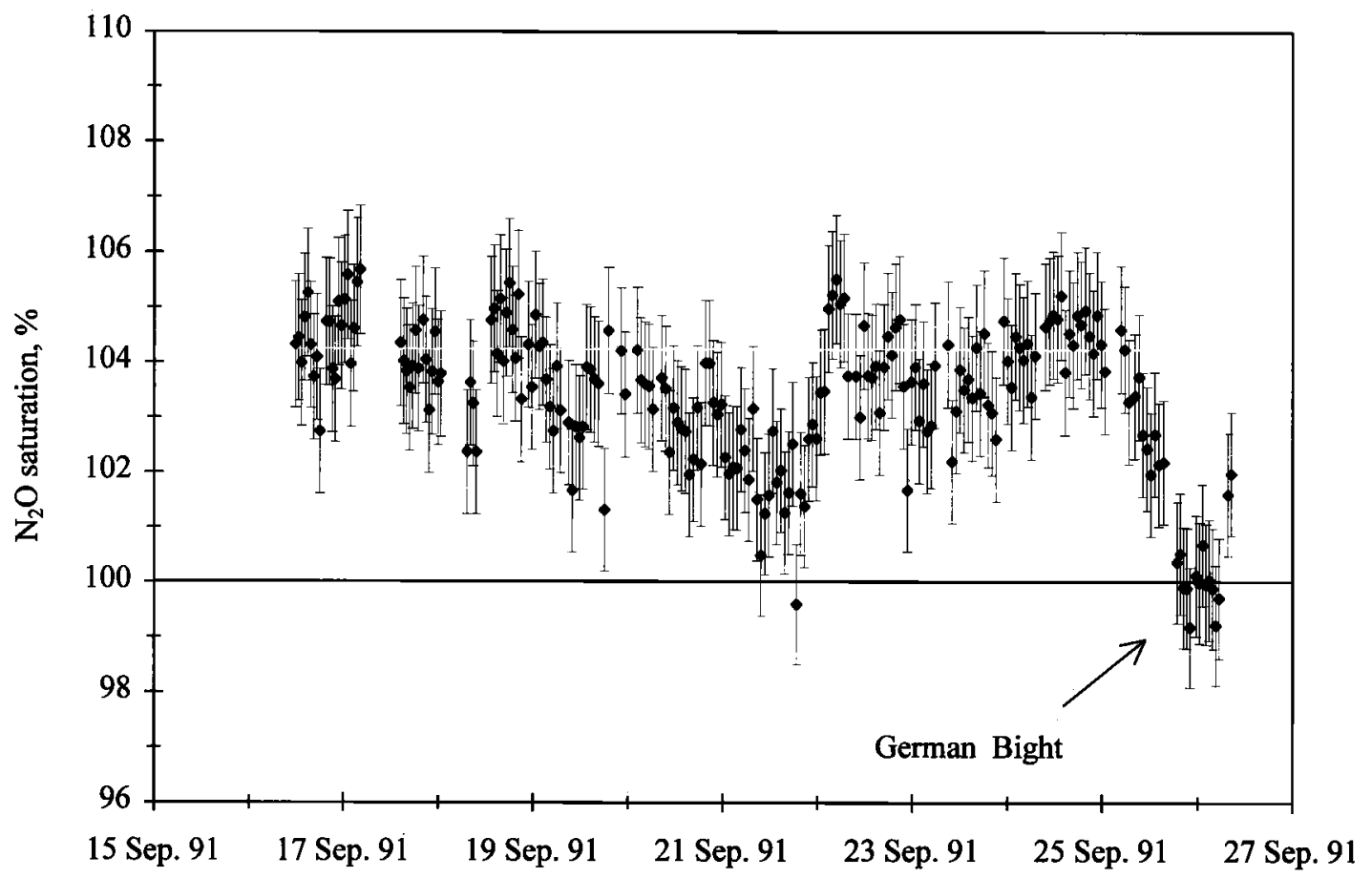

Figure 5. $\mathrm{N}_{2} \mathrm{O}$ saturations in the central North Sea/German Bight region in September 1991 . 


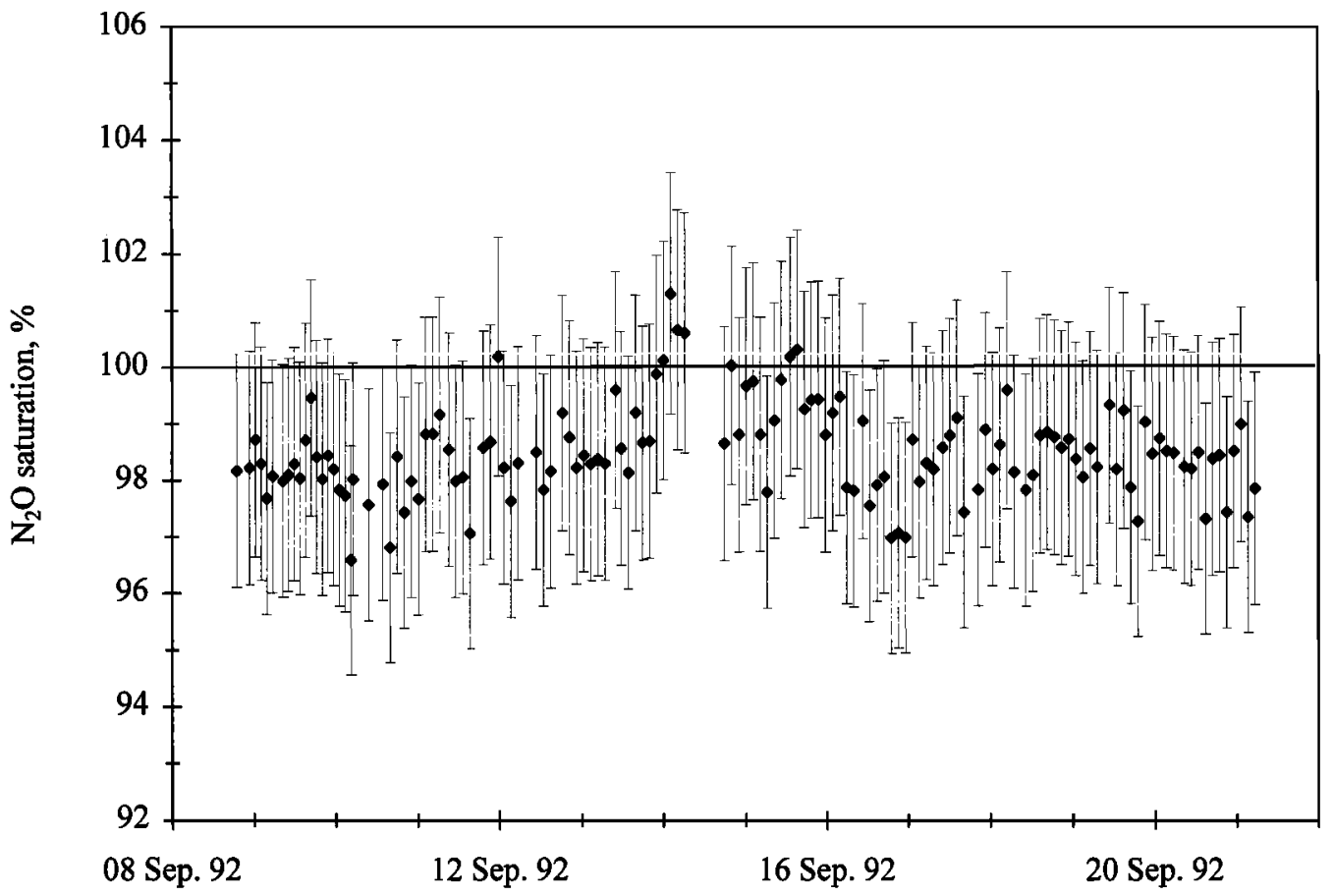

Figure 6. $\mathrm{N}_{2} \mathrm{O}$ saturations at the R/P Nordsee located in the German Bight in September 1992.

we were sampling coastal water masses not influenced by the estuary outflow. The plot of dissolved $\mathrm{N}_{2} \mathrm{O}$ versus salinity exhibits a nonlinear correlation (Figure 7). Deviation from a linear relationship is an indicator for nonconservative behavior of dissolved $\mathrm{N}_{2} \mathrm{O}$ in the Gironde estuary [Boyle et al., 1974; Officer, 1979]. A mass balance model based on the assumption of nonconservative behavior for $\mathrm{N}_{2} \mathrm{O}$ suggested that the ventilation loss of $\mathrm{N}_{2} \mathrm{O}$ from the estuarine waters is balanced by its release from the sediments [Bange, 1994]. This result is an agreement with observations of several authors who concluded that sedimentary production (besides wastewater effluents) could be a significant source for dissolved $\mathrm{N}_{2} \mathrm{O}$ in estuaries and rivers [McElroy et al., 1978; Jensen et al., 1984; Butler et al., 1987; Seitzinger, 1988; Hemond and Duran, 1989; Law et al., 1992].

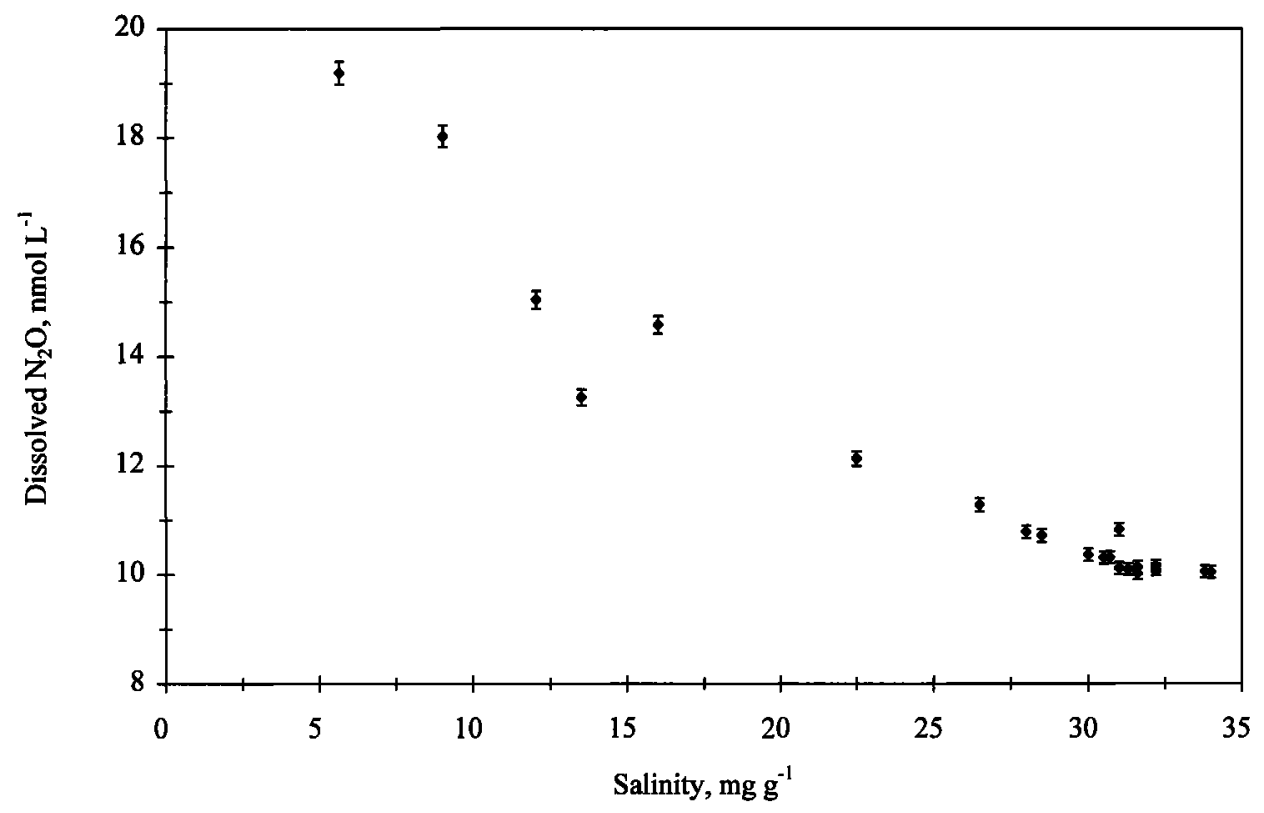

Figure 7. $\mathrm{N}_{2} \mathrm{O}$ water concentrations in the Gironde estuary in November 1991. 


\section{Nitrous Oxide in Coastal Waters}

On the basis of hydrographic (i.e., seawater temperature and salinity distributions), biological (i.e., primary production), and bathymetric classifications, the world's ocean can be divided into four main categories: (1) open ocean, (2) coastal waters, (3) coastal upwelling regions, and (4) estuaries. Whereas the categories open ocean and estuaries are readily defined, coastal waters and coastal upwelling areas are more difficult to distinguish. Under category 2 we grouped both shallow shelf seas (e.g., the North and Baltic Seas) and marginal seas with deep-sea basins (e.g., Mediterranean Sea, Caribbean Sea, Red Sea). This definition of category 2 seems to be suitable because the oceanic nitrogen cycle is closely coupled to atmospheric processes (e.g., $\mathrm{NO}_{3}{ }^{-}$and $\mathrm{NH}_{4}^{+}$deposition). Therefore, the coastal (i.e., the terrestrial) influence is not only restricted to very nearshore regions [e.g., Owens et al., 1992; Schäfer et al., 1993; Cornell et al., 1995] but reaches considerable distances offshore, especially in enclosed seas. Coastal upwelling regions were defined as the "classical" upwelling regions such as the northwestern Indian Ocean, Peruvian coast, Guinea Upwelling, etc., but also include adjacent regions (eastern Arabian Sea shelf) and regions with regional upwelling phenomena (western Bay of Bengal). Table 2 gives compilations of $\mathrm{N}_{2} \mathrm{O}$ measurements in estuaries and coastal areas according to the categories explained above, and Table 3 lists the mean saturation values calculated for each oceanographic region. It is obvious that the highest mean $\mathrm{N}_{2} \mathrm{O}$ saturations were observed in estuarine systems (607\%) and coastal upwelling areas $(176 \%)$. Saturations found in estuarine systems are strongly influenced by the amount of nitrogen-rich wastewater effluents. Nearly pristine estuarine systems (e.g., Yaquina Bay and Gironde) show considerably lower saturations than estuaries with

Table 2. Compilation of $\mathrm{N}_{2} \mathrm{O}$ Saturations in Estuaries, Coastal Waters, Marginal Seas, and Coastal Upwelling Regions

\begin{tabular}{|c|c|c|c|c|c|}
\hline & $\begin{array}{c}\mathrm{N}_{2} \mathrm{O} \text { Saturation, } \\
\text { Percent }\end{array}$ & $\begin{array}{c}\text { Mean }^{b} \mathrm{~N}_{2} \mathrm{O} \\
\text { Saturation, } \\
\text { Percent }\end{array}$ & $\begin{array}{l}\text { Number of } \\
\text { Stations }\end{array}$ & Date & Reference \\
\hline \multicolumn{6}{|c|}{ Estuaries } \\
\hline Gironde & $106-165$ & 132 & 9 & Nov. 1991 & c \\
\hline Amvrakikos Golf & $94-107$ & 101 & cont. & July 1993 & d \\
\hline Tamar & $100-330^{\mathrm{a}}$ & 215 & 25 & Aug., Oct. 1988; May 1989; June 1990 & $0^{\mathrm{e}}$ \\
\hline Elbe & $199-1600^{2}$ & 900 & 2 & Jan. - Dec. 1988 & $f$ \\
\hline Schelde & $120-3000$ & 1560 & 15 & Oct. 1978 & g \\
\hline Yaquina Bay & $100-400^{a}$ & 250 & 9 & Oct. 1983 - Aug. 1984 & h \\
\hline Alsea Bay & $90-239$ & 165 & 5 & July - Sept. 1979 & $\mathbf{i}$ \\
\hline Hudson & $117-700$ & 409 & 14 & Mar. - Sept. 1978 & g \\
\hline Chesapeake Bay & $95-130^{a}$ & 113 & 7 & July 1977 & j \\
\hline Merrimack & $117-455$ & 286 & 14 & Apr., June 1977 & k \\
\hline Potomac Estuary & $100-5000^{\mathrm{a}}$ & 2550 & & July, Sept. 1977 & 1 \\
\hline \multicolumn{6}{|c|}{ Coastal Waters and Marginal Seas } \\
\hline Central North Sea & $104 \pm 1$ & 104 & 26 & Sept. 1991 & c \\
\hline Central North Sea & 102 & 102 & 10 & June 1986; July 1987 & m \\
\hline German Bight & 130 & 130 & 3 & June 1986 ; July 1987 & $\mathbf{m}$ \\
\hline German Bight & $120 \pm 41,114 \pm 36$ & 120,114 & 12 & May, Aug. 1988 & f \\
\hline German Bight & $99 \pm 1$ & 99 & 1 & Sept. 1992 & c \\
\hline Southern and centralBaltic Sea & $96 \pm 1$ & 96 & 68 & Feb. 1992 & $n$ \\
\hline Southern and central Baltic Sea & $103 \pm 1$ & 103 & 23 & July/Aug. 1992 & n \\
\hline Central and northern Baltic Sea & $99-148$ & 135 & 20 & July, Sept. 1977; July $1979 ;$ June 1980 & $j^{\circ}$ \\
\hline Central Baltic Sea & $100,103^{\mathrm{a}}$ & 102 & 1 & Aug. 1986; July 1988 & $\mathrm{p}$ \\
\hline Aegean Sea & $105 \pm 2$ & 105 & cont. & July 1993 & d \\
\hline Golfe du Lion & $75-130$ & 103 & 20 & Dec. 1988 - Jan. 1989 & q \\
\hline Mediterranean Sea & $123-197^{\mathrm{a}}$ & 160 & 10 & Aug. - Sept. 1981 & r \\
\hline Mediterranean Sea & $99-108^{2}$ & 104 & cont. & Dec. 1977 & s \\
\hline Red Sea & $97-133^{a}$ & 115 & cont. & Dec. 1977 - Jan. 1978 & s \\
\hline Gulf of St. Lawrence & $109^{\mathrm{a}}(107-114)$ & 109 & & June 1972 & ' \\
\hline St. Margaret's Bay & $103^{\mathrm{a}}(100-105)$ & 103 & & June 1972 & ' \\
\hline Caribbean Sea & $104-112^{2}$ & 106 & 2 & Mar. 1972 & ' \\
\hline Southem Caribbean Sea & $116^{\mathrm{a}}$ & 116 & 1 & Mar. - Apr. 1979 & $u$ \\
\hline Caribbean Sea & $99-102^{a}$ & 101 & cont. & Nov. 1977 & s \\
\hline Eastern Caribbean Sea & $97-103^{a}$ & 100 & cont. & Dec. 1982 & s \\
\hline Cariaco Trench, WestBasin & $107-113$ & 110 & 1 & Mar. 1986 & v \\
\hline Cariaco Trench, East Basin & $71^{\mathrm{a}}, 91^{\mathrm{a}}$ & 81 & 2 & Mar. - Apr. 1979 & $u$ \\
\hline Amazon Shelf & $100-113^{a}$ & 107 & cont. & Dec. 1982 & s \\
\hline Argentine Shelf & $100-105^{\mathrm{a}}$ & 103 & cont. & Feb. 1988 & s \\
\hline Rio de la Plata & $100-103^{a}$ & 102 & cont. & Mar. 1989 & s \\
\hline Argentine Shelf & $99-101^{\mathrm{a}}$ & 100 & cont. & June 1986 & s \\
\hline Wedell Sea, Antarctica & $103-119^{a}$ & 111 & cont. & Sept. - Dec. 1986 & s \\
\hline Western Cook Strait, New Zealand & $102-119$ & 111 & 2 & Apr. 1983 & w \\
\hline
\end{tabular}


Table 2. (continued)

\begin{tabular}{|c|c|c|c|c|}
\hline $\begin{array}{c}\mathrm{N}_{2} \mathrm{O} \text { Saturation, } \\
\text { Percent }\end{array}$ & $\begin{array}{c}\operatorname{Mean}^{\mathrm{b}} \mathrm{N}_{2} \mathrm{O} \\
\text { Saturation, } \\
\text { Percent }\end{array}$ & $\begin{array}{l}\text { Number of } \\
\text { Stations }\end{array}$ & Date & Reference \\
\hline
\end{tabular}

\begin{tabular}{|c|c|c|c|c|c|}
\hline \multicolumn{6}{|c|}{ Coastal Upwelling Regions } \\
\hline NW Indian Ocean & $187 \pm 40$ & 187 & 11 & Sept./Oct. 1986 & $\mathbf{x}$ \\
\hline NW Indian Ocean & $105-122^{\mathrm{a}}$ & 114 & cont. & Jan. 1978 & $\mathbf{s}$ \\
\hline Eastern Arabian Sea shelf & $137,183,201$ & 174 & 3 & Dec. 1988 & y \\
\hline Gulf of Aden & $106-161$ & 134 & cont. & Jan. 1978 & $s$ \\
\hline Coast of Portugal & $103-113^{\mathrm{a}}$ & 108 & cont. & June - July 1981 & $\mathbf{s}$ \\
\hline Southern Canary Upwelling & $104-129^{a}$ & 117 & cont. & Jan. 1983 & s \\
\hline Off coast Guinea & $103-126^{\mathrm{a}}$ & 115 & cont. & Oct. 1983 & s \\
\hline Off coast Guinea & $102-120^{\mathrm{a}}$ & 111 & cont. & Dec. 1987 - Jan. 1988 & s \\
\hline Off coast Guinea & $102-125^{\mathrm{a}}$ & 114 & cont. & Mar. 1988 & $\mathbf{s}$ \\
\hline Peruvian Coast & 632, ca. 450 & 541 & & Mar. 1978, Feb. - Mar. 1985 & 2 \\
\hline Peruvian Coast & $264,247,224$ & 245 & 2 & Mar. 1976 & aa \\
\hline Off coast Baja California & $182,126,133$ & 147 & 2 & Mar. 1976 & aa \\
\hline Western Bay of Bengal & 161 & 161 & 1 & Mar. - Apr. 1991 & ab \\
\hline
\end{tabular}

Cont. indicates continuous measurements.

${ }^{a}$ Estimated if a saturation value was not explicitly given.

${ }^{\mathrm{b}}$ The mean was calculated as the arithmetical mean from the range given in column two or taken from the literature.

c Source is this paper (see Table 1). ${ }^{\mathrm{d}}$ Bange et al. [1995a]; ${ }^{\mathrm{E}}$ Law et al. [1992]; ${ }^{\mathrm{f}}$ Hanke and Knauth [1990]; ${ }^{\mathrm{g}}$ Deck [1981]; ${ }^{\mathrm{h}}$ Butler et al. [1987]; ' De Angelis and Gordon [1985]; ${ }^{j}$ Elkins et al. [1978]; ${ }^{\mathrm{k}}$ Kaplan et al. [1978]; ${ }^{\mathrm{l}}$ McElroy et al. [1978]; ${ }^{\mathrm{m}}$ Law and Owens [1990a]; " H. W. Bange et al., (1995b); ${ }^{\circ}$ Rönner [1983]; ${ }^{\mathrm{p}}$ Brettar and Rheinheimer [1991]; ${ }^{\mathrm{q}}$ Law et al. [1989]; ${ }^{\mathrm{r}}$ Lavoie et al. [1982]; ${ }^{\mathrm{s}}$ Weiss et al. [1992]; 'Yoshinari [1976] as cited in work by Hahn [1981]; "Hashimoto et al. [1983]; ${ }^{\circ}$ Butler and Gordon [1986]; " Priscu and Downes [1985]; ${ }^{x}$ Law and Owens [1990b]; ${ }^{y}$ Naqvi and Noronha [1991]; ${ }^{\mathrm{z}}$ Codispoti et al. [1992]; ${ }^{\text {an }}$ Pierotti and Rasmussen [1980]; ${ }^{\mathrm{ab}}$ Naqvi et al. [1994].

Table 3. Mean $\mathrm{N}_{2} \mathrm{O}$ Saturation for Various Oceanic Regions

\begin{tabular}{lccc}
\hline & $\begin{array}{c}\text { Mean } \mathrm{N}_{2} \mathrm{O} \\
\text { Saturation, } \\
\text { Percent }\end{array}$ & $\begin{array}{c}\text { ls.d. of the } \\
\text { Mean } \\
\text { Percent }\end{array}$ & $\begin{array}{c}\text { Range, } \\
\text { Percent }\end{array}$ \\
\hline Central North Sea & 103 & - & $102-104$ \\
German Bight & 116 & 6 & $99-130$ \\
Baltic Sea & 109 & 9 & $96-135$ \\
Mediterranean Sea & 118 & 14 & $103-160$ \\
Red Sea & 115 & - & - \\
St. Lawrence Gulf & 106 & - & $103-109$ \\
Caribbean Sea & 102 & 5 & $81-116$ \\
Amazon shelf & 107 & - & - \\
Argentine shelf & 102 & 1 & $100-103$ \\
Wedell Sea & 111 & - & - \\
Mean coastal waters and & 109 & 4 & $102-118$ \\
$\quad$ marginal seas & & & \\
NW Indian Ocean & 145 & 22 & $114-187$ \\
Eastern Arabian Sea shelf & 174 & 33 & $134-201$ \\
Off coast Portugal & 108 & - & - \\
Southern Canary upwelling & 117 & - & - \\
Guinea upwelling & 113 & 1 & $111-115$ \\
Peruvian coast & 442 & 112 & $245-632$ \\
Off coast Baja California & 147 & 31 & $126-182$ \\
$\begin{array}{l}\text { Western Bay of Bengal } \\
\text { Mean coastal upwelling }\end{array}$ & 161 & - & - \\
$\quad$ regions & 176 & 39 & $108-442$ \\
Estuaries & & & $101-2550$ \\
\hline a & 607 & 236 & \\
\hline
\end{tabular}

${ }^{a}$ Calculated as s.d. $/ n^{0.5}, n$ is the number of values. high nitrogen loading (e.g., Elbe, Scheldt, and Potomac). The mean $\mathrm{N}_{2} \mathrm{O}$ saturations found in shelf waters and marginal seas $(109 \%)$ are much lower, but still significantly higher than those reported for the open ocean (about 103\%) [Butler et al., 1989, Nevison et al., 1995]. However, the range of the mean values of the four categories clearly overlap and indicate high spatial and temporal variability (Figure 8). Furthermore, the listed data are biased by the tendency to make oceanographic measurements in the summer season, and therefore the mean $\mathrm{N}_{2} \mathrm{O}$ saturations are

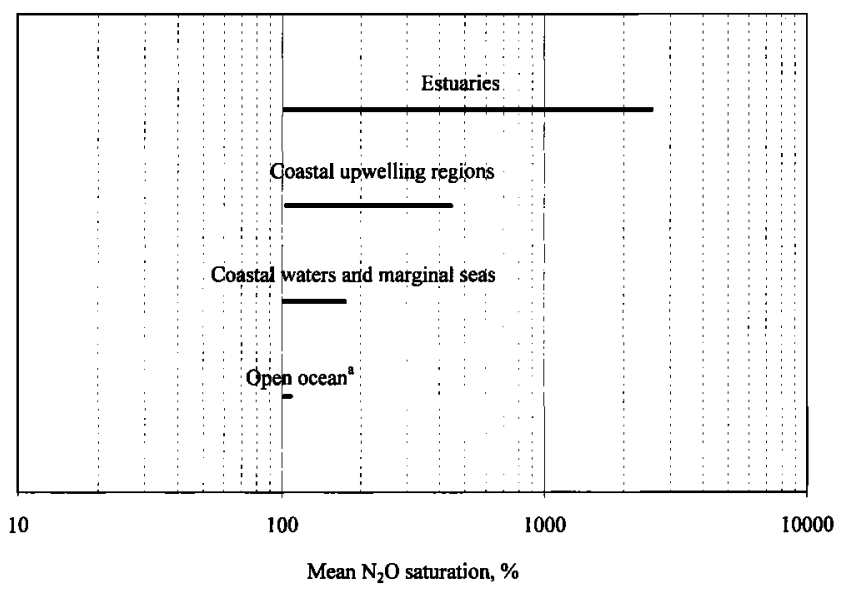

Figure 8. Ranges of mean $\mathrm{N}_{2} \mathrm{O}$ saturations in different oceanographic regions. The data were taken from Table 3 . ${ }^{\mathrm{a}}$ For the open ocean we assumed a range from $102 \%$ to $104 \%$ [Butler et al. 1989; Nevison et al., 1995]. 
probably somewhat overestimated. A pronounced seasonal variability might be caused by different reasons. For example, we have proposed that the variability of the seawater temperature and exchange across the ocean-atmosphere interface might control the $\mathrm{N}_{2} \mathrm{O}$ saturation in the central Baltic Sea, resulting in a saturation maximum during summer (H. W. Bange et al., 1995b). Saturation patterns in the northwestern Indian Ocean found by Weiss et al. [1992] and Law and Owens [1990b] might be driven by monsoonal upwelling events which also occur in the summer months.

On the basis of the data in Table 3 we reassessed the oceanic flux of $\mathrm{N}_{2} \mathrm{O}$ with the aim to evaluate the contributions of coastal regions to the global emissions (Table 4). Using a modified classification of oceanic provinces by Menard and Smith [1966], global annual mean $\mathrm{N}_{2} \mathrm{O}$ transfer coefficients were calculated and then corrected using the Schmidt numbers of $\mathrm{N}_{2} \mathrm{O}$ and $\mathrm{CO}_{2}$ at a salinity of $35 \%$ (for details and uncertainties of the procedure see Bange et al. [1994]). The Schmidt number, defined as ratio of the kinematic viscosity of seawater to the diffusion coefficient of the gas in seawater, was calculated with the equations for the kinematic viscosity cited in work by Siedler and Peters [1986]. The $\mathrm{N}_{2} \mathrm{O}$ diffusion coefficient was derived from the values given by Broecker and Peng [1974]. Two parameterizations of the airsea exchange were applied, the recently published stability dependent model of Erickson [1993] (hereinafter refered to as E93) and the widely used relationship of Liss and Merlivat [1986] (hereinafter refered to as LM86). $\mathrm{N}_{2} \mathrm{O}$ fluxes $F$ across the air-sea interface were calculated with the equation

$$
F=A \cdot k_{w} \cdot\left(S R \cdot C_{a}-C_{u}\right)
$$

where $k_{w}$ is the $\mathrm{N}_{2} \mathrm{O}$ transfer coefficient, $S R$ is the saturation ratio $\left(S R=\right.$ saturation/100), $A$ is the area of the oceanic region, and $C_{a}$ is the equilibrium seawater concentration calculated with the equation of Weiss and Price [1980] for a tropospheric mixing ratio of $310 \mathrm{ppbv}$, a salinity of $35 \%$ (except for the estuarine region where we used $18 \%$ ), and area-weighted annual sea surface temperatures (Table 4 ).

The sum of the fluxes for categories 1-4 (the flux excluding estuaries is given in parentheses) yielded global oceanic fluxes of 17 (12) $\mathrm{Tg} \mathrm{N}_{2} \mathrm{O} \mathrm{yr}^{-1}$ (E93) and 11 (7) $\mathrm{Tg} \mathrm{N}_{2} \mathrm{O} \mathrm{yr}^{-1}$ (LM86) (Table 4). The discrepancy between the two values shows the great uncertainties which are introduced by different air-sea exchange models. Transfer coefficients derived from ${ }^{14} \mathrm{C}$ measurements and dual-tracer experiments indicated that calculations based on the approach of Liss and Merlivat [1986] seem to underestimate the gas transfer coefficient [Wanninkhof et al., 1993]. Thus our calculations suggest that the global oceanic $\mathrm{N}_{2} \mathrm{O}$ flux lies in the range from 11 to $17 \mathrm{Tg} \mathrm{N}_{2} \mathrm{O} \mathrm{yr}^{-1}$ considering the result of the Liss and Merlivat [1986] model as a lower limit and the result of the Erickson [1993] model as a upper limit. Generally, two approaches are used in the literature to derive global $\mathrm{N}_{2} \mathrm{O}$ flux estimations: (1) a geochemical approach based on the measured concentration difference across the oceanatmosphere interface (this approach was used here) and (2) a biological approach using denitrification/nitrification processes as a measure for $\mathrm{N}_{2} \mathrm{O}$ formation. Our estimate is significantly higher than previously published estimates based on the geochemical approach. Butler et al. [1989] and Elkins [1989] calculated with the equations of Liss and Merlivat [1986] a flux of 2.2-4.1 $\mathrm{Tg} \mathrm{N}_{2} \mathrm{O} \mathrm{yr}^{-1}$ using measurements from the Pacific and

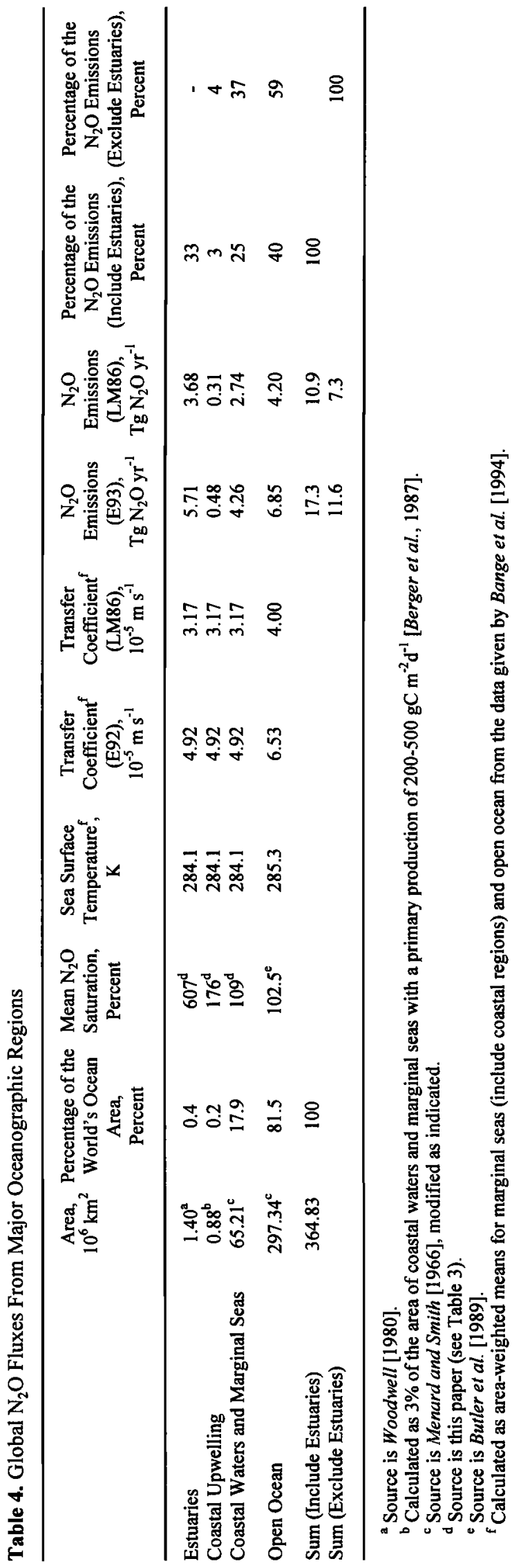


Indian Oceans. However, Butler et al. [1989] stated that the results might have been lowered considerably by the El-Niño effect in 1987. Moreover, Nevison et al. [1995] recently applied three different air-sea exchange models [Liss and Merlivat, 1986; Wanninkhof, 1992; Erickson, 1993] and, using the data sets of Butler et al. [1989] and Weiss et al. [1992], estimated the global $\mathrm{N}_{2} \mathrm{O}$ emissions to range from 1.9 to $10.7 \mathrm{Tg} \mathrm{N}_{2} \mathrm{O} \mathrm{yr}^{-1}$. The difference between our estimate and those discussed above might be caused by the insufficient consideration of coastal areas. On the other hand, our estimate is lower than estimations based on biological approaches. For example, Capone [1991] used denitrification and nitrification fluxes to compute an annual flux of $18 \mathrm{Tg} \mathrm{N}_{2} \mathrm{O}$ for the world's ocean. Furthermore, Wollast [1993] computed an atmospheric flux of $21 \mathrm{Tg} \mathrm{N}_{2} \mathrm{O} \mathrm{yr}{ }^{-1}$ resulting from sedimentary denitrification processes in coastal zones.

Despite the fact that coastal regions occupy only about $18 \%$ of the world's ocean area they contribute approximately $41 \%$ to the global oceanic $\mathrm{N}_{2} \mathrm{O}$ emissions. This value increases considerably when estuarine fluxes are included (60\%) (Table 4). We found agreement with Capone's [1991] and Wollast's [1993] estimates who attributed $49 \%$ and $38 \%$ of the global emissions to coastal areas. We conclude from the data in Table 4 that coastal areas play a significant role in the oceanic budget of $\mathrm{N}_{2} \mathrm{O}$. Estuaries and coastal upwelling regions in particular show a considerable potential for $\mathrm{N}_{2} \mathrm{O}$ emissions and their emissions were underestimated in previous estimations. However, the accuracy of current estimates of the oceanic flux of $\mathrm{N}_{2} \mathrm{O}$ from coastal regions still suffer from the limited database available and the neglect of seasonal variability.

\section{Summary}

The surface waters of the central North Sea and the German Bight were found to be near equilibrium with the overlying atmosphere. We found mean saturation values of $104 \pm 1 \%$ (central North Sea) and 99-101\% (German Bight). The mean saturation in the Gironde estuary was $132 \%$. An estimation of the oceanic fluxes of $\mathrm{N}_{2} \mathrm{O}$, based on a compilation of literature data, indicates that in previous studies the contribution of coastal areas (including estuaries and upwelling regions) were seriously underestimated. We computed, by using the approaches of Liss and Merlivat [1986] and Erickson [1993], an annual global seato-air flux of $11-17 \mathrm{Tg} \mathrm{N}_{2} \mathrm{O}$ and attributed $60 \%$ of this flux to coastal areas.

Acknowledgments. We are grateful to G. Schebeske for technical support and we thank the captains and crews of the R/V Alkor, R/V Côte d'Aquitaine, and R/P Nordsee for their helpful assistance at sea. We appreciate the support of O.F.X. Donard (University of Bordeaux) who enabled us to participate on the Gironde expedition and who provided the CTD data of this cruise. We thank D.J. Erickson (National Center for Atmospheric Research, Boulder, Colorado) for providing the matrices of the transfer coefficients and the sea surface temperatures. The campaigns on the R/V Alkor and R/P Nordsee were part of the EUROTRAC subproject ASE. This research was supported by the Max Planck Society.

\section{References}

Bange, $\mathrm{H}$. W., Messungen von Lachgas $\left(\mathrm{N}_{2} \mathrm{O}\right)$ und Methan $\left(\mathrm{CH}_{4}\right)$ in europaischen Nebenmeeren, Ph.D. thesis, 173 pp., University of Mainz, 1994.

Bange, H. W., U. H. Bartell, S. Rapsomanikis, and M. O. Andreac,
Methane in the Baltic and North Seas and a reassessment of the marine emissions of methane, Global Biogeochem. Cycles, 8, 465$480,1994$.

Bange, H. W., S. Rapsomanikis, and M. O. Andreae, The Aegean Sea as a source of atmospheric nitrous oxide and methane, Mar. Chem., in press, 1995a.

Berger, W. H., K. Fischer, C. Lai, and G. Wu, Oceanic productivity and organic carbon flux, I, Overview and Maps of Primary Production and Export Production, SIO Ref. 87-30, Scripps Inst. of Oceanogr., La Jolla, Calif., 1987.

Bouwman, A. F., K. W. Van der Hoek, and J. G. J. Olivier, Uncertainties in the global source distribution of nitrous oxide, $J$. Geophys. Res., 100, 2785-2800, 1995.

Boyle, E., R. Collier, A. T. Dengler, J. M. Edmond, A. C. Ng, and R. F. Stallard, On the chemical mass-balance in estuaries, Geochim. Cosmochim. Acta, 38, 1719-1728, 1974.

Brettar, I., and G. Rheinheimer, Denitrification in the Central Baltic: Evidence for $\mathrm{H}_{2} \mathrm{~S}$ oxidation as motor of denitrification at the oxicanoxic interface, Mar. Ecol. Prog. Ser., 77, 157-169, 1991.

Broecker, W. S., and T.-H. Peng, Gas exchange rates between air and sea, Tellus, 26, 21-35, 1974.

Butler, J. H., and J. W. Elkins, An automated technique for the measurements of dissolved $\mathrm{N}_{2} \mathrm{O}$ in natural waters, Mar. Chem., 34, 47-61, 1991.

Butler, J. H., and L. I. Gordon, Hydroxylamine and nitrous oxide over the Cariaco Trench, West Basin, 14-17 March 1986, Rep. for $R / V$ Columbus Iselin Cruise CI 860I, Leg 2, Coop. Inst. for Res. in Environ. Sci., Univ. of Colo./NOAA, Boulder, Colo., 1986.

Butler, J. H., R. D. Jones, J. H. Garber, and L. I. Gordon, Seasonal distribution and turnover of reduced trace gases and hydroxylamine in Yaquina Bay, Oregon, Geochim. Cosmochim. Acta, 5l, 697-706, 1987.

Butler, J. H., J. H. Elkins, C. M. Brunson, K. B. Egan, T. M. Thompson, T. J. Conway, and B. D. Hall, Trace gases in and over the West Pacific and East Indian Oceans during the El Niño-Southern Oscillation event of 1987, NOAA Data Rep. ERL ARL-16, Air Resour. Lab., Silver Spring, Md., 1988.

Butler, J. H., J. W. Elkins, T. M. Thompson, and K. B. Egan, Tropospheric and dissolved N2O of the West Pacific and Indian Oceans during the El Niño Southern Oscillation event of $1987, J$. Geophys. Res., 94, 14,865-14,877, 1989.

Capone, D. G., Aspects of the marine nitrogen cycle with relevance to the dynamics of nitrous oxide and nitric oxide, in Microbial Production and Consumption of Greenhouse Gases, edited by J. E Rogers and W. E. Whitman, pp. 255-275, Am. Soc. Microbiol., Washington, 1991.

Cicerone, R. J., Analysis of sources and sinks of atmospheric nitrous oxide $\left(\mathrm{N}_{2} \mathrm{O}\right)$, J. Geophys. Res., 94, 18,265-18,271, 1989.

Codispoti, L. A., J. W. Elkins, T. Yoshinari, G. E. Friederich, C. M. Sakamoto, and T. T. Packard, On the nitrous oxide flux from productive regions that contain low oxygen waters, in Oceanography of the Indian Ocean, edited by B. N. Desai, pp. 271-284, Oxford, New Dehli, 1992.

Cornell, S., A. Rendell, and T. Jickells, Atmospheric inputs of dissolved organic nitrogen to the oceans, Nature, 376, 243-246, 1995.

Crutzen, P. J., and U. Schmailzl, Chemical budgets of the stratosphere, Planet. Space Sci., 31, 1009-1032, 1983.

De Angelis, M. A., and L. I. Gordon, Upwelling and river runoff as sources of dissolved nitrous oxide to the Alsea Estuary, Oregon, Estuarine Coastal. Shelf Sci., 20, 375-386, 1985.

Deck, B. L., Nutrient-element distributions in the Hudson Estuary, Ph.D. thesis, 396 pp., Columbia University, New York, 1981.

Elkins, J. W., State of research for atmospheric nitrous oxide $\left(\mathrm{N}_{2} \mathrm{O}\right)$ in 1989, Contribution for the Intergovernmental Panel on Climate Change (IPCC), NOAA, Boulder, Colo., 1989.

Elkins, J. W., S. C. Wofsy, M. B. McElroy, C. E. Kolb, and W. A Kaplan, Aquatic sources and sinks for nitrous oxide, Nature, 275, 602-606, 1978.

Erickson III, D. J., A stability dependent theory for air-sea gas exchange, J. Geophys. Res, 98, 8471-8488, 1993.

Hahn, J., Nitrous oxide in the oceans, in Denitrification, Nitrification and Aimospheric Nitrous Oxide, edited by C. C. Delwich, pp. 191277, John Wiley, New York, 1981. 
Hanke, V.-R., and H.-D. Knauth, $\mathrm{N}_{2} \mathrm{O}$-Gehalte in Wasser- und Luftproben aus dem Bereich der Tideelbe und der Deutschen Bucht, Vom Wasser, 75, 357-374, 1990.

Hashimoto, L. K., W. A. Kaplan, S. C. Wofsy, and M. B. McElroy, Transformation of fixed nitrogen and $\mathrm{N}_{2} \mathrm{O}$ in the Cariaco Trench, Deep Sea Res., Part A, 30, 575-590, 1983.

Hemond, H. F., and A. P. Duran, Fluxes of $\mathrm{N}_{2} \mathrm{O}$ at the sediment-water and water-atmosphere boundaries of a nitrogen-rich river, Water Resour. Res., 25, 839-846, 1989.

Jensen, H. B., K. S. Jørgensen, and J. Sørensen, Diurnal variation of nitrogen cycling in coastal, marine sediments, II, Nitrous oxide emission, Mar. Biol., 83, 177-183, 1984.

Jouanneau, J. M., and C. Latouche, The Gironde estuary, Contrib. to Sedimentol., IO, 1-115, 1981.

Kaplan, W. A., J. W. Elkins, C. E. Kolb, M. B. McElroy, S. C. Wofsy, and A. P. Duran, Nitrous oxide in fresh water systems: An estimate for the yield of atmospheric $\mathrm{N}_{2} \mathrm{O}$ associated with the disposal of human waste, Pure Appl. Geophys., 116, 423-438, 1978.

Khalil, M. A. K., and R. A. Rasmussen, The global sources of nitrous oxide, J. Geophys. Res., 97, 14,651-14,660, 1992.

Ko, M. K. W., N. D. Sze, and D. K. Weisenstein, Use of satellite data to constrain the model-calculated atmospheric lifetime for $\mathrm{N}_{2} \mathrm{O}$ : Implications for other trace gases, J. Geophys. Res., 96, 7547-7552, 1991.

Krüger, O., ASE/NOSE September 1991, Description of meteorological situations with numerical weather prediction and satellite images, in EUROTRAC Air Sea Exchange Experiment North Sea 14-27 September 1991, Rep. to the UK Dep. of the Environ., edited by T. D. Jickells and L. J. Spokes, Appendix 2, pp. 1-10, University of East Anglia, Norwich, 1992.

Lashof, D. A., and D. Ahuja, Relative contributions of greenhouse gas emissions to the global warming, Nature, 344, 529-531, 1990.

Lavoie, D. M., D. F. Reid, I. P. DePalma, and J. D. Hayes, Chemical, biological, and physical measurements from the Mediterranean Sea, Summer 1980, NORDA Tech. Note 138, Nav. Ocean Res. and Dev. Activity, NSTL Station, Miss., 1982.

Law, C. S., and N. J. P. Owens, Denitrification and nitrous oxide in the North Sea, Neth. J. Sea Res., 25, 65-74, 1990a.

Law, C. S., and N. J. P. Owens, Significant flux of atmospheric nitrous oxide from the northwest Indian Ocean, Nature, 346, 826-828, $1990 \mathrm{~b}$.

Law, C. S., A. P. Rees, and N. J. P. Owens, Consumption and production of nitrous oxide in the Golfe Du Lion, in EROS 2000, Water Pollution Research Report 13, First Workshop on the North-West Mediterranean Sea, edited by J.-M. Martin and H. Barth, pp. 155161, Commission of the European Communities, Paris, 1989.

Law, C. S., A. P. Rees, and N. J. P. Owens, Nitrous oxide: Estuarine sources and atmospheric flux, Estuarine Coastal Shelf Sci., 35, 301$314,1992$.

Liss, P. S., and L. Merlivat, Air-sea exchange rates: Introduction and synthesis, in The Role of Air-Sea Exchange in Geochemical Cycling, edited by P. Buat-Ménard, pp. 113-127, D. Reidel, Norwell, Mass., 1986.

McElroy, M. B., J. W. Elkins, S. C. Wofsy, C. E. Kolb, A. P. Duran, and W. A. Kaplan, Production and release of N2O from the Potomac Estuary, Limnol. Oceanogr., 23, 1168-1182, 1978.

Meier-Reimer, E., Some effects of the Atlantic circulation and of river discharges on the residual circulation of the North Sea, Dt. hydrogr. Z., 32, 126-130, 1979.

Menard, H. W., and S. M. Smith, Hypsometry of the ocean basin provinces, J. Geophys. Res., 71, 4305-4325, 1966.

Minschwaner, K., R. J. Salawitch, and M. B. McElroy, Absorption of solar radiation by $\mathrm{O}_{2}$ : Implications for $\mathrm{O}_{3}$ and lifetimes of $\mathrm{N}_{2} \mathrm{O}$, $\mathrm{CFCl}_{3}$, and $\mathrm{CF}_{2} \mathrm{Cl}_{2}, J$. Geophys. Res., 98, 10,543-10561, 1993.

Naqvi, S. W. A., and R. J. Noronha, Nitrous oxide in the Arabian Sea, Deep Sea Res., Part A, 38, 871-890, 1991.

Naqvi, S. W. A., D. A. Jayakumar, M. Nair, M. D. Kumar, and M. D. George, Nitrous oxide in the western Bay of Bengal, Mar. Chem., 47, 269-278, 1994.

Nevison, C. D., R. F. Weiss, and D. J. Erickson III, Global oceanic emissions of nitrous oxide, $J$. Geophys. Res., I00, 15,809-15,820, 1995.

Officer, C. B., Discussion of the behavior of nonconservative dissolved constituents in estuaries, Estuarine Coastal Mar. Sci., 9, 91-94, 1979.
Otto, L., J. T. F. Zimmermann, G. K. F. Furnes, M. Mork, R. Saetre, and G. Becker, Review of the physical oceanography of the North Sea, Neth. J. Sea Res., 26, 161-238, 1990.

Owens, N. J. P., J. N. Galloway, and R. A. Duce, Episodic atmospheric nitrogen deposition to oligotrophic oceans, Nature, 357, 397-399, 1992.

Pierotti, D., and R. A. Rasmussen, Nitrous oxide measurements in the eastern tropical Pacific Ocean, Tellus, 32, 56-72, 1980.

Prinn, R., D. Cunnold, R. Rasmussen, P. Simmonds, F. Alyea, A. Crawford, P. Fraser, and R. Rosen, Atmospheric emissions and trends of nitrous oxide deduced from 10 years of ALE-GAGE data, $J$. Geophys. Res., 95, 18,369-18,385, 1990.

Priscu, J. C., and M. T. Downes, Nitrogen uptake, ammonium oxidation and nitrous oxide $\left(\mathrm{N}_{2} \mathrm{O}\right)$ levels in the coastal waters of Western Cook Strait, New Zealand, Estuarine Coastal Shelf Sci., 20, 529-542, 1985.

Rodhe, H., A comparison of the contribution of various gases to the greenhouse effect, Science, 248, 1217-1219, 1990.

Ronner, U., Distribution, production and consumption of nitrous oxide in the Baltic Sea, Geochim. Cosmochim. Acta, 47, 2179-2188, 1983.

Schäfer, P., H. Kreilein, M. Müller, and G. Gravenhorst, Cycling of inorganic nitrogen compounds between atmosphere and ocean in tropical areas off South East Asia, in Monsoon Biogeochemistry, edited by V. Ittekkot and R. R. Nair, pp. 19-36, Mitteilungen des Geologisch-Palæontologischen Institut der Universităt Hamburg, SCOPE/UNEP Sonderband, Hamburg, 1993.

Seitzinger, S. P., Denitrification in freshwater and coastal marine ecosystems: Ecological and geochemical significance, Limnol. Oceanogr., 33, 702-724, 1988.

Siedler, G., and H. Peters, Properties of sea water, in Landolt-Börnstein, Oceanography, New Ser., Group V, vol. 3a, edited by J. Sundermann, pp. 233-264, Springer Verlag, New York, 1986.

Sørensen, L. L., O. Hertel, J. Christensen, M. Schulz, and R. M. Harrison, Fluxes of nitrogen gases to the North Sea, in The Proceedings of the EUROTRAC Symposium'94, edited by P. M. Borell, P. Borell, T. Cvitas, and W. Seiler, pp. 626-631, SPB Academic, The Hague, 1994.

Spokes, L., T. Jickells, A. Rendell, M. Schulz, A. Rebers, W. Dannecker, $O$. Kruger, $M$. Leermakers, and W. Baeyens, High atmospheric nitrogen deposition events over the North Sea, Mar. Pollut. Bull., 26, 698-703, 1993.

Wanninkhof, R., Relationship between wind speed and gas exchange over the ocean, J. Geophys. Res., 97, 7373-7382, 1992.

Wanninkhof, R., W. Asher, R. Weppernig, H. Chen, P. Schlosser, C. Langdon, and R. Sambrotto, Gas transfer experiment on Georges Bank using two volatile deliberate tracers, J. Geophys. Res., 98, 20,237-20,248, 1993.

Weiss, R. F., Nitrous oxide in the surface water and marine atmosphere of the North Atlantic and Indian Oceans (abstract), Eos, Trans. AGU, 59, 1101-1102, 1978.

Weiss, R. F., The temporal and spatial distribution of tropospheric nitrous oxide, J. Geophys. Res., 86, 7185-7195, 1981.

Weiss, R. F., and B. A. Price, Nitrous oxide solubility in water and seawater, Mar. Chem., 8, 347-359, 1980.

Weiss, R. F., F. A. Van Woy, and P. K. Salameh, Surface water and atmospheric carbon dioxide and nitrous oxide observations by shipboard automated gas chromatography: Results from expeditions between 1977 and 1990, Rep. SIO 92-11, ORNL/CDIAC-59, NDP044, Carbon Dioxide Info. Anal. Cent., Oak Ridge Natl. Lab., Oak Ridge, Tenne., 1992.

Wollast, R., Interactions of carbon and nitrogen cycles in the coastal zones, in Interactions of $C, N, P$ and $S$ Biogeochemical Cycles and Global Change, edited by R. Wollast, F. T. Mackenzie, and L. Chou, pp. 195-210, Springer-Verlag, New York, 1993.

Woodwell, G. M., Aquatic systems as part of the biosphere, in Fundamentals of Aquatic Ecosystems, edited by R. S. K. Barnes and K. H. Mann, Blackwell Sci., Cambridge, Mass., 1980

Yoshinari, T., Nitrous oxide in the sea, Mar. Chem., 4, 189-202, 1976.

M. O. Andreae, H. W. Bange, and S. Rapsomanikis, Max Planck Institute for Chemistry, Biogeochemistry Department, P. O. Box 3060, D-55020 Mainz, Germany. (e-mail: moa@diane.mpch-mainz.mpg.de; bange@diane.mpch-mainz.mpg.de; rapso@diane.mpch-mainz.mpg.de)

(received May 5, 1995; revised December 20, 1995;

accepted December 21, 1995.) 